\title{
FACTORS AFFECTING AGRICULTURAL INSURANCE ACCEPTABILITY OF PADDY FARMERS IN EAST JAVA, INDONESIA
}

\author{
Sujarwo $^{* 1}$ and Sapto Mei Novita Rukmi*) \\ ${ }^{*}$ Agribusiness Department of Faculty of Agriculture, Universitas of Brawijaya \\ Jl. Veteran Malang 65145
}

\begin{abstract}
Risk and uncertainty in rice farming create more possibility for farmers to lose their profit, which results in the vulnerability of continuing their farming. As noted, rice is the main staple food for Indonesian, and it determines the food security significantly. The aims of the study are to identify rice farmers' acceptance to agricultural insurance, to analyze the factors affecting rice farmers' acceptability for agricultural insurance, and to estimate rice farmers' willingness to pay (WTP) for agricultural insurance. The analyses include descriptive statistics depicting the respondents' characteristics, logistic analysis of the factors affecting the acceptance of agricultural insurance, and the farmers' willingness to pay premium regarding the government program of agricultural insurance for rice farmers. The results show that $80 \%$ of the randomlyselected 50 farmer respondents accept the agricultural insurance. The positive factors affecting the acceptance of agricultural insurance are experience in rice farming and income from rice farming. Other factors considered in the logistic model are not statistically significant. Those factors are farmers' age, education, income from rice farming, experience of rice farming, land size of rice production, the family size, and the experience of accessing any other previous insurance. Additionally, the rice farmers' willingness to pay the premium of agricultural insurance on average is IDR35,113 per hectare. This amount is obtained from the 40 respondents who accept the agricultural insurance program from the government.
\end{abstract}

Keywords: agricultural insurance, premium, willingness to pay, logistic analysis, descriptive statistics

\begin{abstract}
Abstrak: Risiko dan ketidakpastian dalam pertanian padi menciptakan lebih banyak kemungkinan bagi para petani untuk kehilangan keuntungan mereka, yang menghasilkan kerentanan melanjutkan pertanian mereka. Sebagaimana dicatat, beras adalah makanan pokok utama bagi orang Indonesia, dan ini menentukan ketahanan pangan secara signifikan. Tujuan dari penelitian ini adalah mengidentifikasi penerimaan petani padi terhadap asuransi pertanian, untuk menganalisis faktor-faktor yang memengaruhi penerimaan petani padi untuk asuransi pertanian, dan untuk memperkirakan keinginan petani padi untuk membayar (WTP) untuk asuransi pertanian. Analisis meliputi statistik deskriptif yang menggambarkan karakteristik responden, analisis logistik dari faktor yang mempengaruhi penerimaan asuransi pertanian, dan keinginan petani untuk membayar premi terkait program pemerintah asuransi pertanian untuk petani padi. Hasilnya menunjukkan bahwa $80 \%$ dari 50 responden petani yang dipilih secara acak menerima asuransi pertanian. Faktor-faktor positif yang memengaruhi penerimaan asuransi pertanian adalah pengalaman pada pertanian padi dan pendapatan dari pertanian padi. Faktor-faktor lain yang dipertimbangkan dalam model logistik tidak signifikan secara statistik. Faktor-faktor tersebut adalah usia petani, pendidikan, pendapatan dari usahatani padi, pengalaman bertani padi, ukuran lahan produksi beras, ukuran keluarga, dan pengalaman mengakses asuransi lain sebelumnya. Selain itu, keinginan petani padi untuk membayar premi asuransi pertanian rata-rata adalah Rp35.113 per hektar. Jumlah ini diperoleh dari 40 responden yang menerima program asuransi pertanian dari pemerintah.
\end{abstract}

Kata kunci: asuransi pertanian, premium, kemauan membayar, analisis logistik, statistik deskriptif

\footnotetext{
${ }^{1}$ Corresponding author:

Email: sujarwo.ub@gmail.com
} 


\section{INTRODUCTION}

Risk and uncertainty are one of the major issues in agricultural development. Ray (1981) classified the agricultural risks into natural risk, social risk, and economic risk. Natural risks include climate changes, pests and disease attacks, and other natural hazards. Social risks are defined as the factors that affect agricultural production negatively, such as changing in social structures which weaken agricultural resources, social conflicts, and other related factors. Finally, economic risks are the risks in agricultural production due to the effect of economic factors such as price fluctuations, decreased public or private investment in agriculture, and other factors.

The discussion of risk and uncertainty problem in agriculture then can be addressed through the behavior of managing the risk and uncertainty and/ or addressing the way how to cope with the catastrophic effect of risk and uncertainty in sustainable farming of small scale farmers. Agricultural insurance is one of the alternatives considered as the solution for coping with the catastrophic effect of risk and uncertainty in agricultural production. Small-scale farming and low income farmers in developing countries, such as those in Indonesia, is one of those that are exposed to a lot of agricultural insurance.

Pasaribu (2010) found that agricultural insurance has been widely used in many countries as a form of government intervention in preventing farmers from significant losses in their production due to pests and disease attacks, climate changes and other factors influencing negatively in their farming productions. Moreover, agricultural insurance is also a means of government to boost production and give more certainty in their resource allocations and productions. In this perspective, the agricultural insurance will complete another government intervention in agricultural development such as input subsidies and farmers' institutional development.

Considering some experience in China, Wang et al. (2010) found that there are four prerequisites for running agricultural insurance successfully, i.e. (1) enough participation of farmers in accessing agricultural insurance, (2) appropriate rate of premium applied in the agricultural insurance, (3) data base of farming for determining appropriate probabilities of the risk and risk premium, and (4) the analysis for determining actuarially fair of premium rate applied. Experience from China regarding agricultural insurance also showed that the participation of farmers in agricultural insurance was low, which was $1-2 \%$ of farmers. Wang promoted the idea for increasing farmer's participation through the variation of rate premium and its coverage. This scenario gives the farmers an alternative about which coverage and premium rate is preferred to be bought by farmers. Data is also important information for proving whether the probability of bad state is high or not. Therefore, the level of actuarially fair premium will be different regarding the probability of the risk that happened.

Garrindo and Zilberman (2008) informed the development of agricultural insurance in Spain as a developed country implementing agricultural insurance along with other OECD countries, such as United State and Canada, was influenced by some factors, such as premium subsidies, direct payments, and products price volatility. Risk aversion is also the primary factor in stimulating farmers to buy agricultural insurance. This study also found that the larger probability of having production failure was not associated with more frequent insurance participation. This gives more understanding that farmers in Spain especially prefer developing self-insured mechanism by managing risk and giving more opportunity to avoid it strategically. Farmers' expectation regarding premium and their involvement in agricultural insurance is relatively high, and it becomes a challenge for the government to make sure that the agricultural insurance program is conducted effectively and can give benefits as expected by farmers. Furthermore, the results inform that adverse selection is not the primary factor regarding the agricultural insurance participation as the high loss ratio was not convincingly related to the insurance participation. Finally, farmers will be maintained to buy agricultural insurance if they still have nonzero probabilities of obtaining indemnities in the long run.

This research attempts to reveal the farmers' preference regarding the agricultural insurance in the research location and to give information regarding the characteristics of farmers that accept agricultural insurance for maintaining sustainability of their agricultural production and livelihood. Moreover, through the interview guided by structured questions in the questionnaire, this research also reveals the farmers' willingness to pay the premium regarding rice farming. 


\section{METHODS}

This research was conducted in Mangunrejo Village, Kepanjen District, Malang Regency, East Java Province, Indonesia. Moreover, the data was collected from survey from March to April 2017.

The data were collected from a face-to-face interview using questionnaires. Simple random sampling is applied to determine the sample size. The number of sample taken for this research based on the formula promoted by Parel et al. (1978) is as follows:

$$
\mathrm{n}=\left(\mathrm{N} \cdot \mathrm{Z}^{2} \cdot \mathrm{S}^{2}\right) /\left(\mathrm{N} \cdot \mathrm{d}^{2}+\mathrm{Z}^{2} \cdot \mathrm{S}^{2}\right)
$$

Where: N (number of population); n (sample size); $\sigma^{2}$ (population variance of primary variable considered); $\mathrm{d}$ (the level of error accepted in the estimation); $\mathrm{Z}$ (Normal distribution of selected significant level).

Having 371 of rice farmers in the village, 1.96 of $\mathrm{Z}$ at $5 \%$ significant level, the estimated variance of land is 0.025 hectare, and maximum error accepted is $5 \%$, the result of sample size is around 50 respondents.

This research is observing the farmers' behavior regarding agricultural insurance promoted by the government. Accessing the insurance means that the farmers tend to become risk averse more than risk neutral. This will be confirmed by the direct statement of the farmers whether he/she will buy the premium of insurance or not after having got explanation about the rules of the insurance offered. First, a farmer who wants to access the insurance should be a member of the farmers' group. Second, the government will inform the coverage per hectare, which is based on average of existing or actual costs per hectare, and the farmer should provide the information regarding the previous year production. Third, the farmer will get indemnity insurance, which is equal to the cost spent on average costs regarding the land used for rice production if there is loss more than $75 \%$. Fourth, in order to get indemnity insurance the farmer should pay premium for that coverage. Under this insurance design, the farmer will reveal his preference for accessing the agricultural insurance.

After we get information about whether the respondents prefer the insurance or not, this information will be used to develop logistic model of the farmers' preference regarding the agricultural insurance. The model is presented below.

$$
\begin{aligned}
\mathrm{L}= & \ln (\mathrm{p} 1 /(1-\mathrm{p} 1)) \\
= & \beta 0+\beta 1 . \mathrm{AGE}+\beta 2 . \mathrm{EDU}+\beta 3 . \mathrm{INC}+\beta 4 . \mathrm{EXP}+ \\
& \beta 5 . \mathrm{LAND}+\beta 6 . \mathrm{F} \_\mathrm{MEM}+\beta \text { 7.D } 1
\end{aligned}
$$

Where AGE is the age of farmer respondent (years), EDU is education of head of family (years), INC is income for rice farming (IDR), EXP is experience in rice farming (years), LAND is the land size of rice production (hectare), F_MEM is family members (person), and D1 $=1$ if there is an experience of accessing insurance and $\mathrm{D} 1=0$ if there is no experience of it.

The dominant theory explaining about risk-taking decisions is developed by Morgenstein and Neumann (1953). The representation of decision making in risk conditions is by maximizing the expected utility rather than maximizing profit. This concept consists of 3 components, namely expected outcomes, the tendency of outcomes that are indicated by probability distribution, and the existence of utility over outcomes (Hurley, 2010). Furthermore, Rothchild and Stiglitz (1970) provides an analysis of which options are riskier than others. This concept is also known as stochastic dominance (Mas-Colell et al. 1995). For the riskaversion person, the first stochastic dominance says that the lower variance of the alternative at the same average level is preferred than the higher one (Vickson, 1977).

Farmers are working in an uncertain condition and facing risk and uncertain output due to the facts that agricultural productions depend on weather, biological process, and the environment. Therefore, the bad state as well as good state of production exists in their production activities. Generally, the risk and uncertainty facing by farmers can be reduced by the farmers' experience and capability of understanding the weather and controlling the use of available resources. However, the availability of inputs and the market are not easily predicted, and these can affect the livelihood of farmers not only in the sort term but also in the longrun. The failure of production seems to easily shut down the next production and pushes the farmers' family into poverty. This generally happens to small scale farmers in the rural areas. 
Representing the risk and uncertainty and the importance of covering the farmers' losses through insurance can be depicted as follows. The person who is uninsured will face uncertainty results whether he/ she will get a good thing or bad thing of his/her wealth. Then, the corresponding utility function is U1. For insured person, he/she will face certainty regardless what occurrence will happen and the utility function is U2 (Figure 1).

Suppose that the individual is at risk averse and the probability of good state happening is $\mathrm{P}$; then, there are two points, $\mathrm{A}$ and $\mathrm{B}$, which have the same expected value of wealth; however, point $A$ is the expected value with the risk and point $\mathrm{B}$ is the expected value without the risk. Since the person is at risk averse, he/she will prefer B than A. Therefore, the utility function of B is higher than that of A. Moreover, the risk averse person will sacrifice (A1-B1) of his/her wealth in order to avoid the risk. That value is called risk premium. If the person is at risk neutral, which means that the person does not consider risk in his/her decision, then point A and point B are the same in his/her utility. In other words, he/she is not willing to pay the insurance.

\section{RESULTS}

The characteristics of farmers regarding the age, family members, education, income from rice production, experience of rice farming, and land size of rice farming are shown in Table 1. Sixty-four\% of farmers age more than 55 years. Most of them graduated from elementary school or less, i.e. about $62 \%$, and the actual gross income from rice farming is generally in the range between IDR 1.0 million and 4.9 million. On average, the farmers' land size in the research location is 0.28 hectare and the standard deviation is about 0.14 hectare. Moreover, the farmers' experience regarding rice farming is more than 10 years.

Those are the picture of the farmers in the research sample, which are relatively low in education and low in land size ( 0.28 hectare on average). Having those constraints will make farmers in risky situation. The implication of these limited resources will threat sustainability of farmers' paddy production. It means that the absence of government intervention and the farmers' low education will cause catastrophic problem to them and their families.

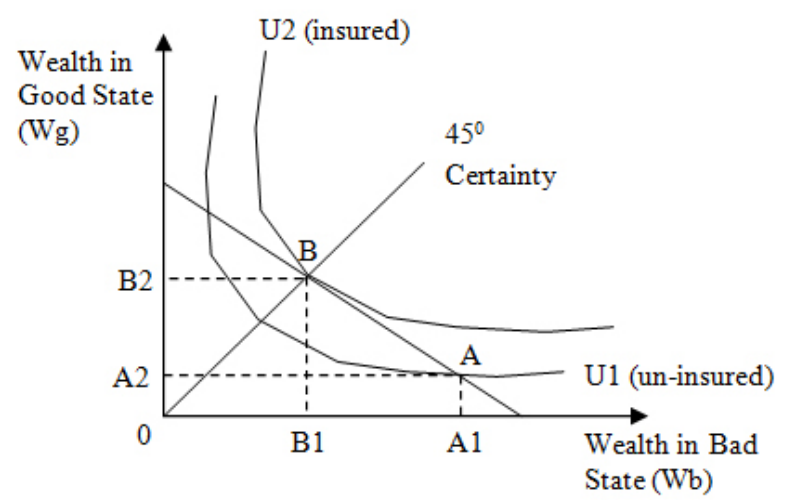

Figure 1. Insured and un-insured utility level of wealth

Table 1. The respondents' characteristics

\begin{tabular}{|c|c|c|c|}
\hline Characteristics & Category & $\begin{array}{l}\text { Number } \\
\text { of farmers } \\
\text { (Person) }\end{array}$ & $\begin{array}{c}\text { Percentage } \\
(\%)\end{array}$ \\
\hline \multirow[t]{4}{*}{ Age } & $35-44$ & 6 & 12 \\
\hline & $45-54$ & 12 & 24 \\
\hline & $55-64$ & 20 & 40 \\
\hline & $\geq 65$ & 12 & 24 \\
\hline \multirow{3}{*}{$\begin{array}{l}\text { Family } \\
\text { members }\end{array}$} & $1-3$ & 20 & 40 \\
\hline & $4-6$ & 30 & 60 \\
\hline & $\geq 7$ & 0 & 0 \\
\hline \multirow[t]{6}{*}{ Education } & No education & 3 & 6 \\
\hline & $\begin{array}{l}\text { Not finished } \\
\text { Elementary }\end{array}$ & 7 & 14 \\
\hline & Elementary & 21 & 42 \\
\hline & $\begin{array}{l}\text { Junior high } \\
\text { school }\end{array}$ & 7 & 14 \\
\hline & $\begin{array}{l}\text { Senior high } \\
\text { school }\end{array}$ & 8 & 16 \\
\hline & $\begin{array}{l}\text { Higher } \\
\text { education }\end{array}$ & 4 & 8 \\
\hline \multirow{5}{*}{$\begin{array}{l}\text { Income } \\
\text { offarmers in } \\
\text { acrual size } \\
\text { ofland (IDR) }\end{array}$} & $<1.000 .000$ & 0 & 0 \\
\hline & $\begin{array}{l}1.000 .000- \\
<2.400 .000\end{array}$ & 29 & 58 \\
\hline & $\begin{array}{l}2.400 .000- \\
<4.900 .000\end{array}$ & 20 & 40 \\
\hline & $\begin{array}{l}4.900 .000- \\
<1.400 .000\end{array}$ & 1 & 2 \\
\hline & $>7.400 .000$ & 0 & 0 \\
\hline \multirow{4}{*}{$\begin{array}{l}\text { Land size } \\
\text { (hectare) }\end{array}$} & $<0.2$ & 16 & 32 \\
\hline & $0.2-<0.3$ & 19 & 38 \\
\hline & $0.3-<0.4$ & 2 & 4 \\
\hline & $0.4-<0 . S$ & 13 & 26 \\
\hline \multirow[t]{5}{*}{ Experience } & $\leq 10$ & 5 & 10 \\
\hline & $11-20$ & 21 & 42 \\
\hline & $21-30$ & 11 & 22 \\
\hline & $31-40$ & 12 & 24 \\
\hline & $>40$ & 1 & 2 \\
\hline
\end{tabular}


Noticing the years of experience of paddy farmers in Table 1 and the resources own by farmers, there are signals that farmers are not making progress in their paddy production. The farmers' more than 10 years experience in producing paddy in their fields and potential profit are not good enough for capital accumulation. As a result, the farmers' resources are getting lower and threatening their livelihood sustainability in paddy production. Therefore, the agricultural insurance supported by the government is one way of preventing them from coming into the shutting down point in their farming. With regard to the agricultural insurance, the acceptance of the insurance is studied using quantitative approach, logit analysis.

Logit analysis is applied in order to generate information regarding the acceptance of farmers toward agricultural insurance program run by the government. The data were analyzed using SPSS 21 . The results show that the Negelkerke R-Square of the logit model is 0.57 . It means that the variables in the model explain $57 \%$ the farmers' acceptance of agricultural insurance. The overall correct predicted value of accepting the agricultural insurance is $90 \%$. Moreover, the predicted probability based on logit analysis comparing to income from paddy farming and land size is presented below.

It is a relatively clear pattern of the correlation between income level and the acceptance of the agricultural insurance. The farmer who has more income in their paddy farming has more acceptance level in the agricultural insurance. This finding supports the assumption that higher income farmers tend to be more risk averse.

The acceptance level of agricultural insurance is different if it is connected to the farming size. The increasing level of farming size does not clearly show the increasing acceptance in the agricultural insurance. Figure 2 shows the pattern of both agricultural insurance acceptance to income level and agricultural insurance acceptance to farming size.

Continuing the analysis of logit model regarding the characteristics of socio-economic toward agricultural insurance, the results show that the factors significantly and positively affecting the level of acceptance toward agricultural insurance are income of rice farming and the experience in rice farming. Age, education, farming size, family members or family size, and the experience in buying health insurance are not statistically significant to foster the farmers to join the agricultural insurance program.

The finding regarding the income and the agricultural insurance acceptance in this research is supported by the finding of Farzaneh et al. (2017), which found that acceptance toward silkworm insurance are affected by the higher level of income and the small distance of insurance affiliates from the silk farms. Along with those factors is the fair premium level paid by the farmers. Furthermore, Sihem (2017) using logistic regression of 276 cross-section observations of agricultural insurance in American and European countries in the period 2000-2012 found a different result compared to this research result regarding the effect of education on the agricultural insurance acceptance. Sihem found that education played an important role in affecting demand of agricultural insurance. The other factors affecting the demand of agricultural insurance were the government subsidy on premium paid, the yield risk, and also the religion. For other findings related to the developmental factors of agricultural insurance, Yang et al. (2015) observed that the agricultural insurance development in China was significantly influenced by the government subsidy in the premium. Other factors that positively significantly influenced the participation to agricultural insurance were diversity of crop production disaster, the level of farmers' awareness toward agricultural insurance, and the weather factor. However, diversity of income negatively impacted on the farmers' participation for buying agricultural insurance.

According to the table, a number of farmers accept the agricultural insurance, and they are willing to pay the premium about IDR 35,113, and the coefficient variation is $21 \%$. The pilot project of agricultural insurance has been run by the government since 2014 determined the premium level of IDR36,000 (20\%) paid by farmers and IDR144,000 (80\%) paid by government. This is coming from 40 respondents in the research location, while the others, i.e. 10 respondents, are not willing to pay premium for agricultural insurance at all. 

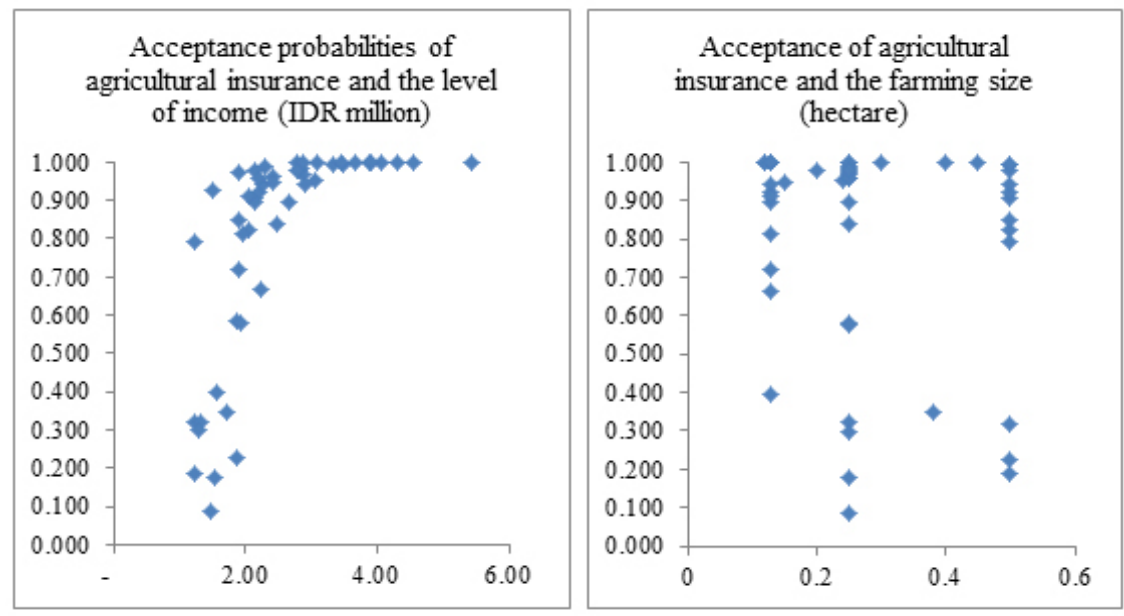

Figure 2. The pattern of farming size, the income and the acceptance probabilities in the agricultural insurance

\section{Managerial Implications}

Managerial implications of these finding can be viewed from the perspective of farmers and government. From the farmers' perspective, the risk and uncertainty in rice farming will affect more in the way how the higher income farmer allocate their resources. Using Rothchild (1970) concept, the farmers who have higher income tend to use more inputs, such as pesticides, to protect their farming from losses. However, it is not clearly related to farming size, as explained in logit result. The existence of agricultural insurance will tend to be more acceptable for the higher income rice farmers. Government, on the other hand, could not promote insurance program for all farmers. The progressive farmers are potential in accepting this program; however, general farmers with lower income and experiences will not participate actively and continuously in agricultural insurance program.

\section{CONCLUSIONS AND RECOMMENDATIONS}

\section{Conclusions}

Farmers' acceptance toward agricultural insurance is relatively high, which is $80 \%$. However, the indemnity offered for the agricultural insurance in this research is higher from what has been offered by government through the pilot project conducted in East-Java and other province in Indonesia. The government offers indemnity about IDR6 million for 1 hectare as the assumption of the cost per hectare paddy production. In this research, the determination of coverage level is based on the average actual cost of rice production in the location, which is on average IDR7.18 million per hectare (explicit cost spent for rice farming), which is higher than what have been offered by government.

Logit analysis giving information related to the characteristic of farmers who have higher possibility in accepting agricultural insurances. The characters of farmers supporting the agricultural insurance program are having higher income and higher experiences. Those characters can be simplified as progressive farmers.

Considering willingness to pay of farmers, the amount of premium willing to be paid by farmers is little bit lower than the part of premium paid by farmers under agricultural insurance program. Government supports $80 \%$ of the premium. The actual total premium is IDR180,000. It means that if the government support of this program is stopped then the farmers will not pay the premium or will not buy the insurance because the willingness to pay of the premium is much lower than the total actual premium.

\section{Recommendations}

Considering the conclusion and the facts regarding the implementation of agricultural insurance, some suggestions can be made for the development of agricultural insurance in Indonesia. They are:

1. For strengthening the program in the future, progressive farmers tend to favor the agricultural insurance program. For this type of farmers, the program should be addressed first. This will increase the success of the program. As a result, other farmers could learn and imitate these farmers in accepting the agricultural insurance program.

2. The coverage of insurance is adjusted to what the cost of farming in specific location. The acceptability 
of agricultural insurance tends to increase when the program can differentiate which location has higher risk and which location has lower one. Higher risk will generate higher premium and lower risk will imply lower rate of premium as well.

3. As stated in the Bayes' theorem, government should provide lower transaction cost in accessing insurance coverage. Therefore, the benefit gaining from the agricultural insurance program can increase the posterior believe of farmers regarding the insurance program.

\section{REFERENCES}

Farzaneh M, Allahyari MS, Damalas CA, Seidavi A. 2017. Crop insurance as a risk management tool in agriculture: The case of silk farmers in northern Iran. Land Use Policy 64: 225-232. https://doi. org/10.1016/j.landusepol.2017.02.018.

Garrido A, Zilberman D. 2008. Revisiting the demand for agricultural insurance: the case of Spain. Agricultural Finance Review 68(1): 43-66. https://doi.org/10.1108/00214660880001218.

Hurley TM. 2010. A Review of Agricultural Production Risk in The Developing World. St. Paul, MN: University of Minnesota, Harvest Choice.

Mas-Colell A, Whinston MD, Green JR. 1995. Microeconomic Theory (Vol. 1). New York: Oxford university press.

Morgenstern O, Neumann VJ. 1953. Theory of games and economic behavior. US: Princeton university press.
Parel CP, Caldito GC, Ferrer PL, De Guzman GG, Sinsioco CS, Tan RH. 1978. Social survey research design. PSSC social survey series 1.

Pasaribu SM. 2010. Developing rice farm insurance in Indonesia. Agriculture and Agricultural Science Procedia 1: 33-41. https://doi.org/10.1016/j. aaspro.2010.09.005.

Ray PK. 1981. Agricultural Insurance: Theory and Practice and Application to Developing Countries. England: Pergamon Press.

Rothschild M, Stiglitz JE. 1970. Increasing risk: I. A definition. Journal of Economic Theory 2(3): 225-243. https://doi.org/10.1016/00220531(70)90038-4.

Sihem E. 2017. Economic and socio-cultural determinants of agricultural insurance demand across countries. Journal of the Saudi Society of Agricultural Sciences 2017:1-11. https://doi. org/10.1016/j.jssas.2017.04.004.

Vickson RG. 1977. Stochastic dominance tests for decreasing absolute risk-aversion II: general random variables. Management Science 23(5): 478-489.https://doi.org/10.1287/mnsc.23.5.478.

Wang E, Yu Y, Little BB, Li Z. 2010. Crop insurance premium design based on survival analysis model. Agriculture and Agricultural Science Procedia 1: 67-75. https://doi.org/10.1016/j. aaspro.2010.09.009.

Yang X, Liu Y, Bai W, Liu B. 2015. Evaluation of the crop insurance management for soybean risk of natural disasters in Jilin Province, China. Natural Hazards 76(1): 587-599. https://doi. org/10.1007/s11069-014-1510-z. 